茶抽出物のヒト株化マスト細胞

ヒスタミン合成酵素に与える影響

\author{
独立行政法人 農業・生物系特定産業技術研究機構 野菜茶業研究所* \\ 森脇佐和子・浅 井 和 美・山本（前田）万里 \\ (平成16年10月21日受理)
}

\title{
Effect of Tea Extracts on Histidine Decarboxylase of Human Mast Cell Line, HMC-1
}

\author{
Sawako Moriwaki, Kazumi Asai and Mari Maeda-Yamamoto \\ National Institute of Vegetable and Tea Science, \\ National Institute Agriculture and Bio-oriented Research Organization
}

\section{Summary}

Recently, it has been increased the allergic disease like the phenomenon of immune hypersensitiveness. Mast cells play a critical role of allergy and release histamine, which is chemical mediator of allergy. Human mast cell line, HMC-1, has a great store of histamine, however, the histamine release is little. Therefore, we paid attention to histamine synthetase (histidine decarboxylase, HDC), and attempted to screen anti-allergic components in tea. HDC gene transcription level of cells was measured with RT-PCR. Among tea cultivars tested, it was shown that HDC expression of mRNA levels was decreased in 'Hatsumomiji', especially. On the other hand, tea catechines have not influenced on expression of HDC mRNA. From these results, we presumed that the lowering of the mRNA expression level is caused by the interaction of various tea components. This study suggested that this assay was useful for the screening of anti-allergic components.

Key words : allergy, histamine, histidine decarboxylase (HDC), mast cell, RT.PCR

\section{1 緒 言}

近年,アレルギー疾患は増加傾向にあり， 特にスギ花粉に対する花粉症症状を持つ人は, 人口のおよそ三割に達するといわれている。 このように国民病といわれるまでに社会問題
化しているアレルギー疾患について，非常に 高い関心が笴せられている。

免疫系は, 生体防御を行う非常に重要な機 構で，アレルギーは，この免疫系の過剩反応 によって起こると考えられており，特にマス 卜細胞の関与が大きいといわれている。

* テ428-8501 静岡県榛原郡金谷町金谷2769 
ヒスタミンは,アミノ酸の一つであるヒス チジンから合成される生体内アミンの一つで, マスト細胞から放出されたヒスタミンは, 粘 膜に存在する神経を刺激して暲みやくしゃみ といった症状を引き起こすといわれている。 そのヒスタミンの合成酵素として，ヒスチジ ン脱炭酸酵素 (Histidine decarboxylase; HDC) が知られ，ヒスチジンのカルボキシル 基を脱炭酸することによりヒスタミンに変換 している。マスト細胞のヒスタミンは抗原 $-\mathrm{IgE}$ 抗体複合体の刺激で遊離され，ヒスタミン $\mathrm{H}_{1}$ 受容体を介した即時型アレルギー反応に関与 している ${ }^{1,2)}$

マスト細胞を指標とした抗アレルギー性の 検定は，細胞加遊離されたヒスタミンを酵 素免疫測定法 (ELISA) または HPLC 法で定 量し, その遊離量から評価している。しかし, 抗アレルギー成分の探索を行う上で，その試 験対象を食品, 中でも茶とした場合, ELISA 法では非特異的な反応が多くみられることに より, 適切な評価ができないのが現状である。 またヒトの株化マスト細胞は，ヒトマスト細 胞性白血病細胞株 'HMC-1'一種のみしか樹立 されておらず3)，この細胞は，ヒスタミンを細 胞内に貯留寸るが，脱顆粒，ヒスタミン遊離 がわずかしか起こらないことが確認されてい る4)。そのため，ほとんどの試験はげっ歯類の 株化マスト細胞やマウス骨髄由来培養マスト 細胞 (BMMC) を調製して行わざるをえない ことから，ヒトの株化細胞を用いた評価系の 構築が望まれている。

HMC-1 は, ヒスタミン遊離という観点から の抗アレルギー性試験の使用には不適である が，細胞内の七スタミン貯留量が多いことよ り, 細胞内ヒスタミン量の変動, さらにヒス タミン合成酵素の発現調節という新たな視点 で，抗アレルギー性を評価できる細胞として 有用であると考えられる。また，アレルギー の詳細なメカニズムはヒトとげっ歯類では異 なるため, 評価試験系にヒト株化細胞である HMC-1 を使用することは,より適切であると 考える。

そこで今回，アレルギーに関与するマスト
細胞のヒスタミン合成醉素であるとスチジン 脱炭酸酵素 (HDC) に着目し, 茶抽出物が HDCに与える影響について検討したので報告 する。

\section{2 実験方法}

\section{1 使用細胞}

細胞は，既存のヒト株化マスト細胞である HMC-1を用いた。この細胞は, IgE と結合す る高親和性 IgEレセプタ（FceRI）の発現が 安定していないため, その構成タンパク質で ある $\alpha$ 鎖または $\beta$ 鎖遺伝子を導入した細胞を 作成した。 $\alpha$ 鎖遺伝子発現べクターは $p$ MKIT F c $\varepsilon$ RI- $\alpha$ （順天堂大学より譲与）を用いた。 $\beta$ 鎖遺伝子 $(0.8 \mathrm{~kb})$ は，哺乳類用発現べクター $p$ CEP4（10.4kb，invitrogen 社製）に組み込 み, $\beta$ 鎖遺伝子発現ベクター $p$ CEP4-Fc $\varepsilon$ RI- $\beta$ を構築したものを用いた。各遺伝子は, Human CD34 Cell Nucleofector Kit ${ }^{\mathrm{TM}}$ (amaxa $\mathrm{GmbH}$ 社製)を用いたエレクトロポレーショ ン法により細胞に導入し, $1 \mathrm{mg} / \mathrm{mL}$ の抗生物 質 $(\alpha$ 鎖: $\mathrm{G} 418, \beta$ 鎖: ハイグロマイシン) で遺伝子導入株を選抜した。得られた遺伝子 導入株のレセプ夕構成サブユニット mRNA は, いず机も発現していることを確認している。

$\alpha$ 鎖または $\beta$ 鎖を高発現する HMC- $1 \alpha$ 鎖高 発現株を $\alpha$ 株, $\beta$ 鎖高発現株を $\beta$ 株とし, 実験 に使用した。各々 $10 \%$ ウシ胎仔血清を含む RPMI1640 培地で $37^{\circ} \mathrm{C}, 5 \% \mathrm{CO}_{2}$ 条件下て培 荃した。

\section{2 試料の調製}

(1) 茶 試 料

茶品種として，“あさぎり，抢くむさし， ただにしき，はつもみじ，ひめみどり，ベに ふうき，やえほ，やまとみどり，やぶきた， 大葉鳥龍” 010 種を，野菜茶業研究所金谷研 究拠点試験圃場で2003年度一番茶期に摘採 後, 電子レンジ乾燥 $(1,600 \mathrm{~W}, 4$ 分程度) さ せたものを試料とした。各々粉研した試料 約 $0.2 \mathrm{~g} 60^{\circ} \mathrm{C}, 10$ 分間蒸留水 $10 \mathrm{~mL}$ で抽出後, 夕 ンニン量が $100 \mu \mathrm{g} / \mathrm{mL}$ になるように蒸留水で希 釈した。なおタンニンの定量は既存の方法淿に 
従った。

(2) カテキン類の調製

主要カテキン類 4 種 (Sigma 社製)のうち, EGCG，EGC はリン酸緩衝食塩水(PBS-)に, ECG, EC $20.6 \%$ DMSO (dimethyl sulfoxide）を含むPBS-に各々可溶化したものを用 いた。

\section{3 ヒスタミン定量法}

細胞内総七スタミン量はオンカラム HPLC 法で定量した ${ }^{6)}$ 。各細胞 $\left(1 \times 10^{6}\right.$ cells $\left./ 1.8 \mathrm{~mL}\right)$ を各茶抽出物共存下 (終濃度 $10 \mu \mathrm{g} / \mathrm{mL}$ ) で $37^{\circ} \mathrm{C}, 5 \% \mathrm{CO}_{2}$ 条件下にて 2 日間培養後, 回 収した細胞を $0.1 \%$ Triton X-100で可溶化し た。その上清に含まれるヒスタミン量を HPLC (LC-10AD システムおよび RF-10AXL 蛍光 検出器（侏島津製作所製）により測定した。 カラムは Shodex Asahipak ODP-50 4 E(4.6 mmi.d. $\times 150 \mathrm{~mm}$,粒径 $5 \mu \mathrm{m}$ ) (昭和電工(侏製) を使用し, $1 \mathrm{mM} o$ - フタルアルデヒド (OPA) および $1 \mathrm{mM} \mathrm{N}$ - アセチルシステインを含むア セトニトリル $/ 50 \mathrm{mM}$ ホウ酸 $(80 / 20, \mathrm{v} / \mathrm{v})$ の溶離液を流速 $0.5 \mathrm{~mL} / \mathrm{min}$ で流し測定した。

\subsection{RT-PCR}

HDC mRNA プライマーは, 既知の HDC mRNA 配列 (NCBI/GenBank data accession No.M60445）より棈築し，フォワードプ ライマーを5'ATC ATC TCC TGC CCC ACT G-3',リバースプライマーを 5'-CAG AAG GCC ATC GAG GAA G-3'として用いた。 細胞内発現標準遺伝子として，ハウスキーピ ング遺伝子の一つである $\beta$ アクチンを用(7), フォワードプライマー5'TGA CGG GGT CAC CCA CAC TGT GCC CAT CTA-3', リバースプライマー5’-CCC TCC ATC GTC CAC CGC AAT GCT TCT AG-3' を構築し て使用した。total RNA は, ISOGEN (日本 ジーン社製) で各細胞から抽出し， CDNA は Ready-to-Go RT-PCR Beads(Amersham Biosciences 社製）を用いて合成した。RTPCR は, iCycler(BIO-RAD 社製) を使用し, $95^{\circ} \mathrm{C}$ で 60 秒, $60^{\circ} \mathrm{C} て ゙ 60$ 秒， $72^{\circ} \mathrm{C} て ゙ 60$ 秒のサイ
クルを35回行い, CDNAを増幅させた。增幅 断片は,アガロースゲル電気泳動で確認した。 バンドの解析は, NIH imageソフトを用い, 相対強度を数值化して表示した。

\section{3 実験結果および考察}

3.1 茶抽出物による細胞内総ヒスタミン量 の変化

著者らはこれまでに, HMC-1 が高濃度の七 スタミンを細胞内に貯留していることを確認

表 1 各ヒトマスト細胞株の 細胞内総ヒスタミン量

\begin{tabular}{cc}
\hline 細胞種 & $\begin{array}{c}\text { 総ヒスタミン量 } \\
\mathrm{ng} / 10^{5} \mathrm{cells}\end{array}$ \\
\hline HMC-1 & $217.658 \pm 37.6$ \\
$\alpha$ 株 & $221.716 \pm 15.6$ \\
$\beta$ 株 & $213.749 \pm 25.5$ \\
\hline & mean \pm SD $(\mathrm{n}=4)$
\end{tabular}

している（表 1)。このことより，HMC-1 は ヒスタミン合成が活発な細胞であると考えら れる。そこで, 茶がヒスタミン合成に変化を 与えるか調べるため，2 日間茶抽出物共存下 で培養した細胞の, 細胞内総七スタミン量を 測定した。茶抽出物の代わりに PBS-を添加し たものをコントロール $(100 \%)$ とし, 各々比 較した。その結果, 誤差が大きくばらつきが 䜑められるものの, 若干ではあるが品種によ りヒスタミン量に増減（>120\%，<80\%）が 認められた（図 1)。

マスト細胞では, $\operatorname{IgE}$ との結合により炎症性 物質の合成が盛んになる ${ }^{1,8 \sim 10)}$ 。またインター ロイキン 4 (IL-4) は，ヒトマスト細胞の増殖 や活性化に関与しているといわれているサイ トカインである ${ }^{10,11}$ 。そこで,これらの因子を 茶抽出物と共培養し(IgE：終濃度 $2 \mu \mathrm{g} / \mathrm{mL}$, IL-4：終濃度 $10 \mathrm{ng} / \mathrm{mL})$, 同様に定量を行っ た。しかしながら，この培湌条件では明確な 差 ( $>120 \%,<80 \%$ ) は認められなかった（図 2 )。 $\alpha$ 株は，“ひめみどり’抢よび IgE, IL4 と共培養した場合に高い值を示したが, 非常 に誤差が大きく，適切な評価が困難であると 


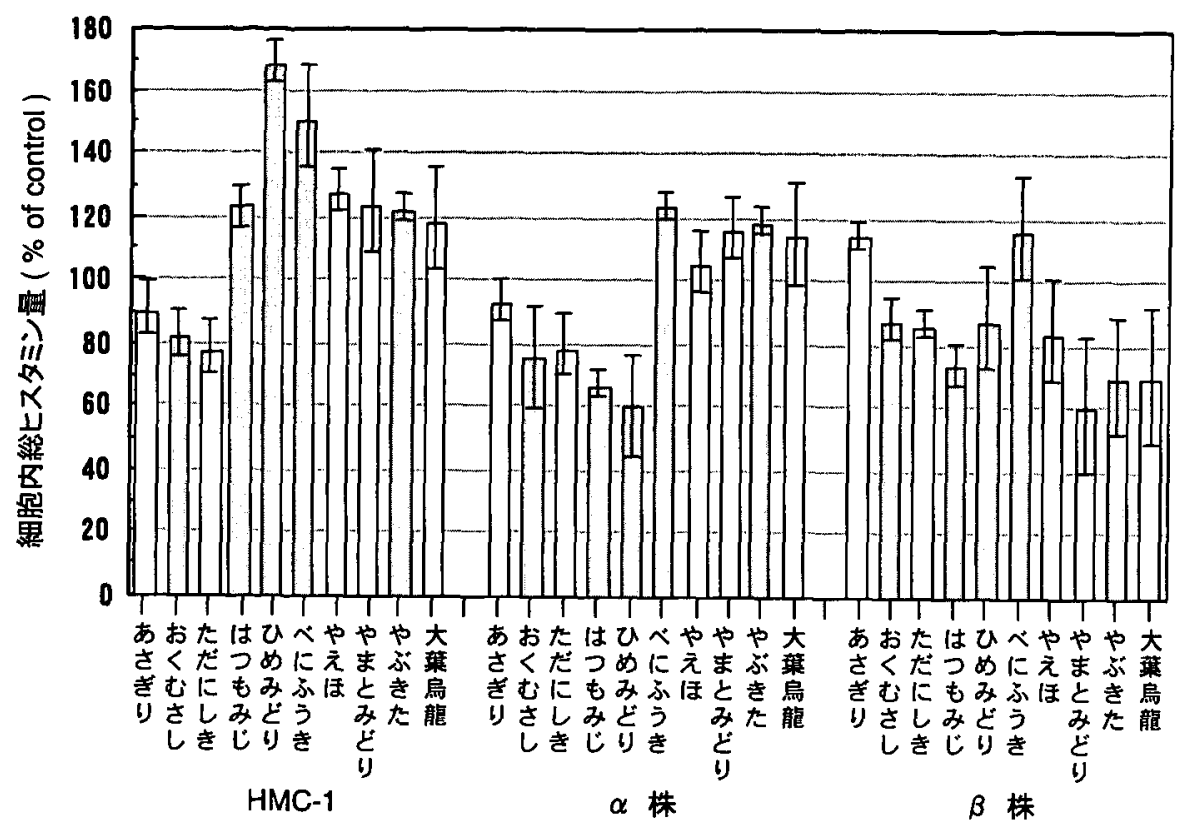

図 1 茶抽出物によるヒト株化マスト細胞内ヒスタミン量の変動

コントロールを $100 \%$ として比較, 培養 2 日後、全ての細胞を回収し 細胞内総ヒスタミン量を定量 $($ mean $\pm \mathrm{SD}(\mathrm{n}=2))$

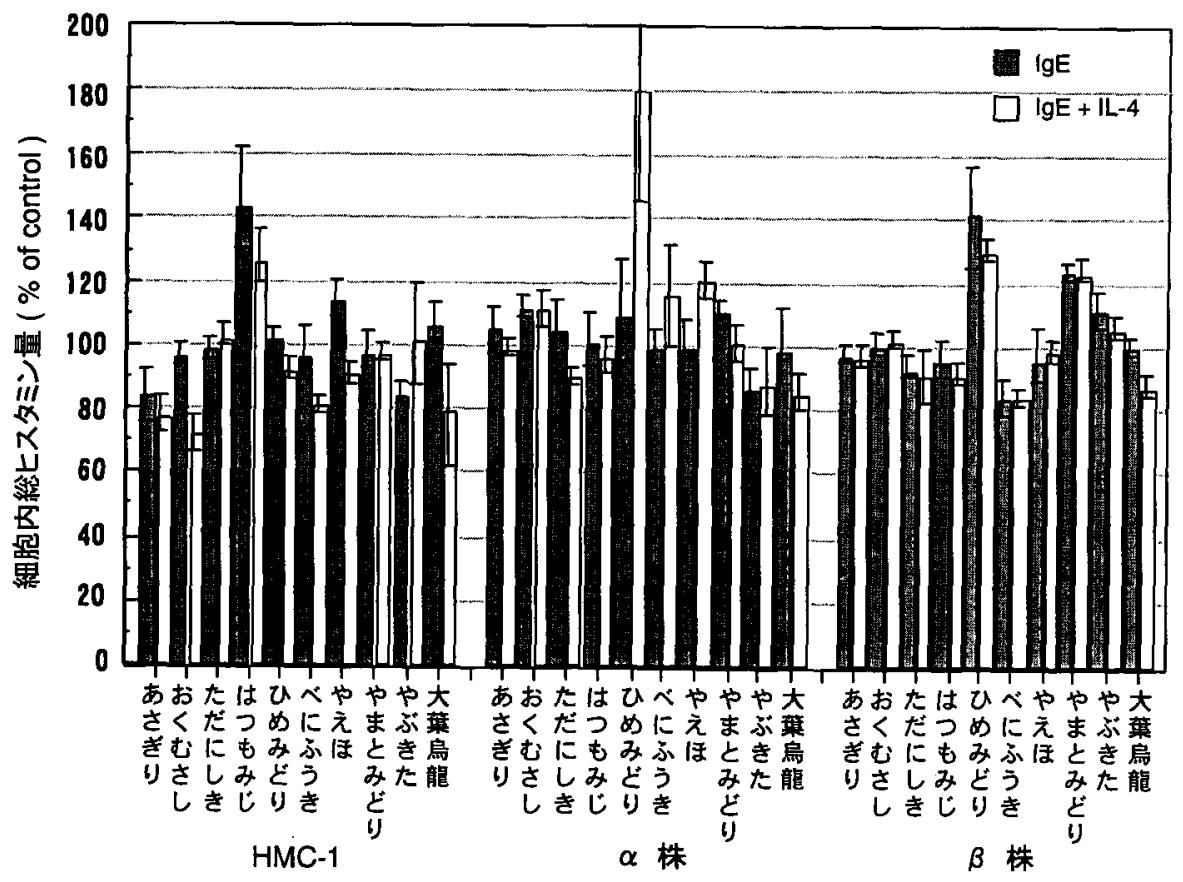

図2ヒト株化マスト細胞に対する茶抽出物およびIgE, IL-4 の影響 コントロールを $100 \%$ として比較, 培養後, 全ての細胞を回収し 紐胞内総七スタミン量を定量 $($ mean $\pm \mathrm{SD}(\mathrm{n}=2))$ 
判断した。

そこで，総ヒスタミン量に変化が見られた 5 品種 “おくむさし，はつもみじ，ひめみど り，べにふうき，やぶきた’に関し，さらに

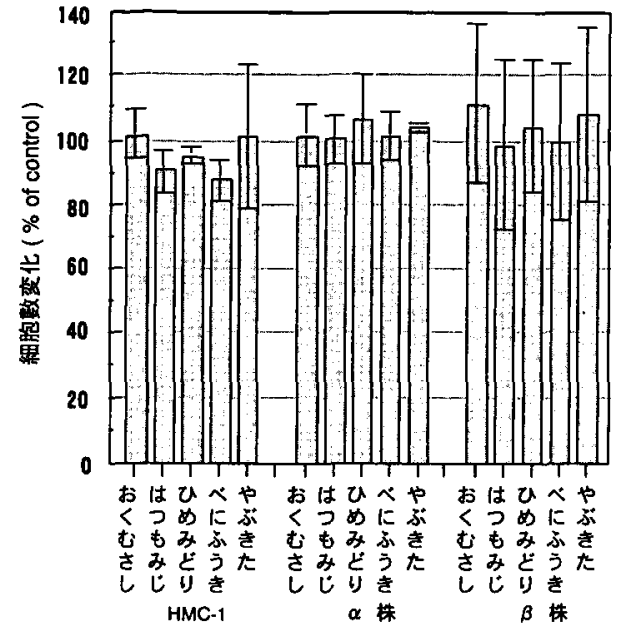

図3各ヒトマスト細胞株に対する茶抽出物 の細胞增殖に関する影響

コントロールを $100 \%$ として比較, 培養 2 日後, 全ての細胞を回収し 細胞数を測定 $($ mean $\pm \mathrm{SD}(\mathrm{n}=3))$

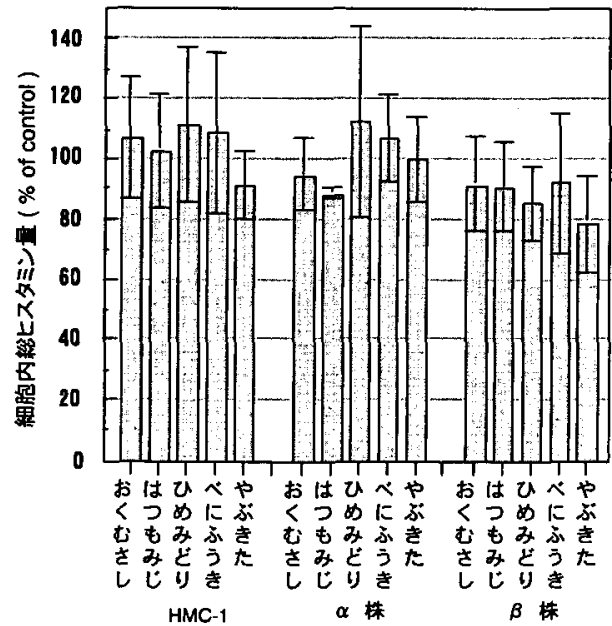

図 4 茶抽出物共存下で培養後 $1.5 \times 10^{6}$ 個 当たりの細胞内総ヒスタミン量の変化 コントロールを $100 \%$ として比較, 培責 2 日後, 細胞数を調整し細胞内 総ヒスタミン量を定量 $($ mean $\pm \mathrm{SD}(\mathrm{n}=3))$
細胞増殖への影響（図 3)，一定個数当たりの 細胞内ヒスタミン量（図 4)について検討し たが，いずれにおいても誤差が大きく，有意 な差は確認できなかった。

以上の結果より, HMC-1 の細胞内総ヒス夕 ミン量は安定しないことが示された。これは, 実験を行う際の細胞の状態や操作などが影響 するものと考えられ，また HMC-1 は，既に高 濃度でヒスタミンを貯留しているため，茶添 加後に合成されるヒスタミンのわずかな変化 量を HPLC 法で検出することが困難である可 能性も示唆された。

\section{2 ヒスタミン合成に茶抽出物が与える影 響}

上記結果を踏まえて,HMC-1 を用いた新た な細胞内ヒスタミン変化量の検出方法を検討 するために，実際にヒスタミンを合成する酵 素であるHDC の発現量に着目した。醉素タン パク質の発現量を指標とする方法は, HPLC 法 とは異なり実際のヒスタミン量の変動は追跡 できないが, HMC-1 の高ヒスタミン合成能と いう特性を有効に活用できると考えた。そこ で，茶抽出物のヒスタミン合成に及ぼす影響 について FceRI レセプタの発現が安定してい る $\beta$ 株を用いて, HDC mRNA の発現量を解 析した(図 5 )。コントロールと比較して HDC mRNA の発現量は，“はつもみじ’において 増加が認められたが, その他の品種では著し い変化は認められなかった。

さらに, IgE および IL-4 共存下で培養した

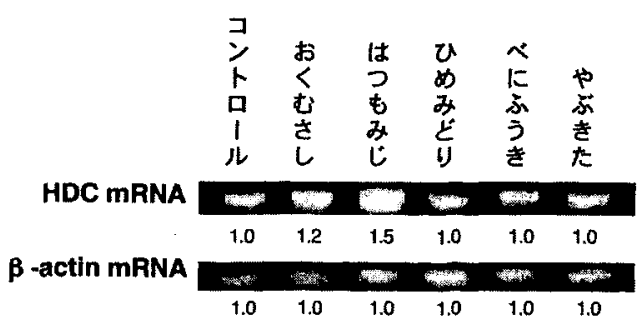

図 5 茶抽出物が HDC に与える影響 $\beta$ 株を用い，図 1 と同様の 培養条件の細胞を供試した， 数字は相対強度を表す。 


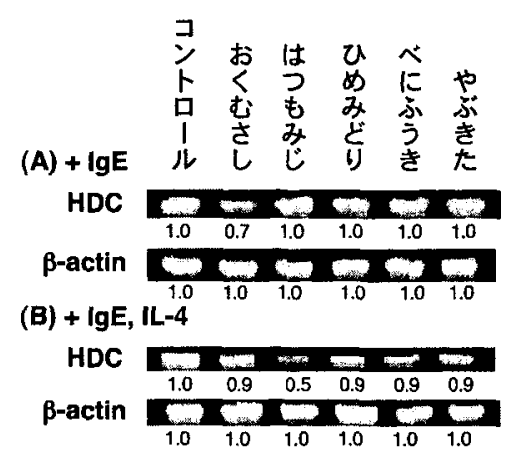

図 $6 \mathrm{IgE}, \mathrm{IL}-4$ 共存下において茶抽出物 がHDC に与える影響

$\beta$ 株を用い, 図 2 と同様の 培養条件の細胞を供試した， 数字は相対強度を表す。

場合についても，前述の方法と同様に検討し た。IgEのみ添加した場合では,いずれも HDC mRNAの発現量に顕著な变化は認められな かった(図 6 A)。しかし，IL-4 を添加した場 合は,いずれの茶抽出物においても HDC mRNAの発現量が低下し，特に“はつもみ じの発現量は著しく低くなった（図6 B)。 上述したように IL-4 は, マスト細胞の活性化 に関与するといわれており, 茶成分がIL-4によ る細胞活性化を抑制し，それに伴いHDC mRNAの転写抑制が起こったと推察された。

以上より，ヒトマスト細胞のヒスタミン合 成量の変化を RT.PCR 法により評価できる可 能性が示された。

\section{3 ヒスタミン合成にカテキン類が与える 影響}

HMC-1 はホルボールミリステートアセテー トやイオノマイシンの様な薬戍刺激によって も活性化される。この薬剤により HMC-1を刺 激した場合, HDC のタンパク質量は増加する が, HDC の mRNA 発現量には変化が認めら れないという報告がある12)。これは, 刺激薬用 が mRNAからタンパク質への翻訳過程に作用 し調節していることを示している。本実験で は, 茶の品種により HDCの mRNA 発現量に 変化が認められており,つまり HDCの mRNA の転写過程を調節するような茶成分が存在す
る可能性が示唆された。

茶抽出物中に存在するカテキン類は，抗酸 化能, 抗ガン作用のみならず, 最近では抗ア レルギー作用など様々な効能を有することで 注目されている茶に特有の成分の一つである。 そこで, HDC mRNA の転写調節にカテキン 類が関与している可能性を, 主要カテキン類 4 種を用いて検討した。

まず，カテキン類の細胞増殖に与える影響 について検討した。2 日間カテキン類共存下 (終濃度 $10 \mu \mathrm{g} / \mathrm{mL}$ ) で培養した細胞の細胞数 をコントロールと比較した。カテキンのみ, または IgE, IL-4 共存下ではいずれも，著しい 変化は認められず,また細胞増殖への影響もほ とんどないことが確認された（デー夕省略）。

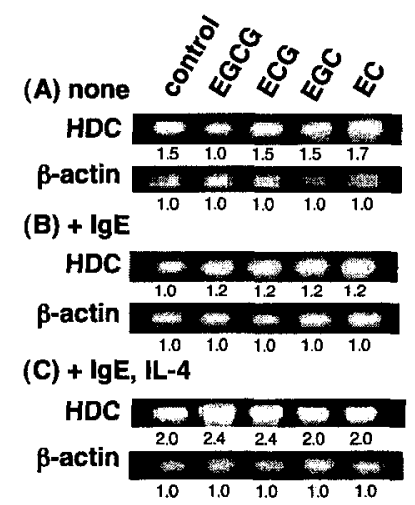

図7 カテキン類がHDCに与える影響

$\beta$ 株を用い, カテキン類および IgE，IL-4 共存下で培養後の細胞を 供試した，数字は相対強度を表す。

次に,前述の方法と同様に HDC の発現量を RT-PCR 法により検討した。HDC@ mRNA 発現量は,コントロールと比較して EGCGを 添加した場合において, 発現の低下が認めら れた(図 $7 \mathrm{~A}$ )。しかし, IgE, IL-4 共存下で はどのカテキン類でもコントロールとの変化 は認められなかった（図7 B，C）。これらの 結果より, HDCの mRNAの転写調節にカテ キン類が与える影響は少ないことが推察された。

これまでに, 緑茶由来の EGCG がラット細 胞の HDC に対し直接作用し,ヒスタミン合成 を抑制するという報告がある13)。この報告では， 
HDC のタンパク質量は EGCGにより変化が認 められないとあり,今回の実験と矛盾しない。 また逆に，フラボンおよびフラボノール類で 処理した HMC-1 では, 細胞内ヒスタミン量が 増加するという報告がある ${ }^{14)}$ これらの報告を 加味すると, HDC の mRNA 発現レベルの低 下は，茶抽出物中の一成分による効果ではな く，様々な成分の相互作用により生じた結果 であると推察された。

これまで, 抗アレルギー性の指標は, 炎症 性物質であるヒスタミンの遊離抑制が主に試 験されていたが，七スタミン合成酵素の発現 抑制という観点からも，抗アレルギー性評価 試験が行える可能性が示された。この手法で は, 添加された食品成分等の実験系への影響 が軽減できると考えられ，また，簡便な手法 であることから汎用性も高いと考えられる。 HMC-1 は, ヒスタミン合成が非常に活発な細 胞であることから，HDC の測定を行う実験系 には非常に有用であり，さらに，株化細胞で あるため, 安定した実験が行える等の利点が 挙げられる。今後, マスト細胞を介するアレ ルギーにおける食品の有効成分等の評価の一 指標として, HDC mRNA の発現解析の利用 が期待される。

\section{4 摘 要}

マスト細胞はアレルギーの中心的役割もち， ヒスタミンなどの炎症性物質を放出する。本 研究では，ヒト株化マスト細胞のヒスタミン 合成酵素 (HDC) に着目し，ヒスタミン合成 に茶抽出物が及柿寸影響について検討した。 その結果, 品種により HDC mRNAの発現量 が異なることが判明した。しかしながら，カ テキン類は HDC mRNAの発現調節に影響を 及ほさなかった。これらの結果より, HDC mRNA 発現量の低下は,様々な茶成分の相互 作用によることが推察された。

\section{5 謝辞}

この実験を遂行するにあたりご協力下さい ました，江間かおりさん，神田えみさん，久 保池千鶴子さんに感謝申し上げます。

\section{6 引用文 献}

1) Tanaka S. (2003) : Physiological function mediated by histamine synthesis. Yakugaku Zasshi, 123, 547-559.

2) 遠藤康男 (2001)：炎症・免疫応答における ヒスチジンデカルボキシラーゼの誘導.日 薬理誌, $118,5-14$.

3 ) Butterfield, J.H., D. Weiler, G. Dewald and G.J. Gleich (1988) : Establishment of an immature mast cell line from a patient with mast cell leukemia. Leuk Res. 12, 345-355.

4) Watanabe, Y., Y. Todome, H. Ohkuni, S. Sakurada, T. Ishikawa, T. Yutsudo, V.A. Fischetti and J.B. Zabriskie (2002): Cysteine protease activity and histamine release from the human mast cell line HMC-1 stimulated by recombinant Streptococcal pyrogenic exotoxin B/ Streptococcal cyteine protease. Infection and Immunity, 70,3944-3947.

5 ）池ヶ谷賢次郎・高柳博次・阿南豊正 （1990）：茶の分析法. 茶研報, No.71, 43-74.

6) Saito, K., M. Horie, N. Nose, H. Nakagomi and H. Nakazawa (1992) : Highperformance liquid chromatography of histamine and 1-methylhistamine with on-column fluorescence derivatization. J. Chromatogr. 595, 163-168.

7) Nakajima-Iijima, S., H. Hamada, P. Reddy and T. Kakunaga (1985) : Molecular structure of the human cytoplasmic $\beta$-actin gene: Interspecies homology of sequence in the introns. Proc. Natl. Acad. Sci. USA, 82, 6133-6137.

8) Boyse, J.A (2003): Mast cells: Beyond IgE. J. Allergy Clin. Immunol. 111, 24-32.

9) Kubo, S., K. Matsuoka, C. Taya, F. Kitamura, T. Takai, H. Yonekawa and H. Karasuyama (2001): Drastic upregulation of $F c \varepsilon R I$ on mast cells is 
induced by IgE Binding through stabilization and accumulation of $F_{c \varepsilon} R I$ on the cell surface. J. Immunol. 167, 3427-3434.

10) Wakahara, S., Y. Fujii, T. Nakao, K. Tsuritani, T. Hara, H. Saito and C. Ra (2001): Gene expression profiles for Fc $\varepsilon R I$, cytokines and chemokines upon FCERI activation in human cultured mast cells derived from peripheral blood. Cytokine. 16,143-152.

11) Bischoff, S.C, G. Sellge, A. Lorentz, W. Sebald, R. Raab and M.P. Manns (1999) : IL-4 enhances proliferation and mediator release in mature human mast cells. Proc. Natl. Acad. Sci. USA, 96, 80808085.

12) Maeda, M., H. Taniguchi, I. Ohno, H. Ohtsu, K. Yamauchi, E. Sakurai, Y. Tanno, J.H. Butterfield, T. Watanabe and K. Shirato (1998) : Induction of Lhistidine decarboxylase in a human mast cell, HMC-1. Experimental Hematology. 26, 325-331.

13) Rodríguez-Caso, C., D. Rodríguez-Agudo, F. Sánchez-Jiménez and M.A. Media (2003): Green tea epigallocatechin-3gallate is an inhibitor of mammalian histidine decarboxylase. Cell. Mol. Life Sci. 60, 1760-1763.

14) Alexandrakis, M., R. Letourneau, D. Kempuraj, K. Kandere-Grzybowska, M. Huang, S. Christosoulou, W. Boucher, D. Seretakis and T.C. Theoharides (2003): Flavones inhibit prolieration and increase mediator content in human leukemia mast cells (HMC-1). Eur. J. Haematol. 71, 448-454. 